\title{
Fabrication and characterization of anode-supported single chamber solid oxide fuel cell based on $\mathrm{La}_{0.6} \mathrm{Sr}_{0.4} \mathrm{Co}_{0.2} \mathrm{Fe}_{0.8} \mathrm{O}_{3-8}{ }^{-}$
}

\section{$\mathrm{Ce}_{0.9} \mathrm{Gd}_{0.1} \mathrm{O}_{1.95}$ composite cathode}

L.P. Sun ${ }^{a, b}$, M. Rieu ${ }^{a, *}$, J.P. Viricelle ${ }^{a}$, C. Pijolat ${ }^{a}$, H. Zhao ${ }^{b}$

${ }^{a}$ Ecole Nationale Supérieure des Mines, SPIN, PRESSIC, CNRS:UMR5307, LGF, F-42023 Saint-Etienne / France

${ }^{\mathrm{b}}$ Key Laboratory of Functional Inorganic Material Chemistry, Ministry of Education, School of Chemistry and Materials Science, Heilongjiang University, Harbin 150080 P. R. China

* Corresponding author: M. Rieu, E-mail address: rieu@emse.fr; Tel.:+33 4774202 82;

Fax:+33477499694 


\begin{abstract}
:
Anode-supported solid oxide fuel cells consisting of nickel-gadolinium doped ceria (NiO-CGO, 60:40 wt $\%$ ) anode, gadolinium doped ceria (CGO) electrolyte and lanthanum strontium cobaltite ferrite-gadolinium doped ceria (LSCF-CGO) cathode are developed and operated under singlechamber conditions, utilizing methane/air mixture. The cell performance is optimized regarding the electrolyte microstructure, cathode composition and testing conditions. The performance of the cell improves with the decrease of the thickness of the electrolyte and the increase of the ratio of methane to oxygen. The test cell with LSCF-CGO cathode $(70: 30 \mathrm{wt} \%)$ that was sintered at $1100{ }^{\circ} \mathrm{C}$ for $2 \mathrm{~h}$ and $150 \mu \mathrm{m}$ dense electrolyte exhibits the maximum power output of $\sim 260 \mathrm{~mW}$ $\mathrm{cm}^{-2}$ at $600^{\circ} \mathrm{C}$ in $\mathrm{CH}_{4} / \mathrm{O}_{2}=2$ atmosphere.
\end{abstract}

Keywords: SOFC; Single Chamber; electrolyte microstructure; LSCF-CGO cathode

\title{
1. Introduction
}

Single-chamber solid oxide fuel cells (SC-SOFCs) have received many attentions in recent years, due to their simplified reactor configuration and capability for quick start-up [1-5]. They have potential applications as micropower generator for portable devices and co-generation of electricity and synthesis gases $[6,7]$. Because they operate on fuel-air mixture, one way to minimize the gas phase reaction that would reduce the electrical efficiency is to adopt fuels with high chemical stability such as hydrocarbons with low carbon numbers, especially methane; another way is to reduce the operation temperature. Usually the operating principle of SC-SOFC is based on the selective catalytic activities of the electrodes towards the fuel/oxygen mixture. The anode must be aimed at the partial oxidation of fuel as well as electrochemically catalytic 
oxidation of $\mathrm{H}_{2}$ and $\mathrm{CO}$, while the cathode must be aimed at the oxygen electrochemically catalytic reduction. During the last years, a number of studies have been reported with the results of different kinds of electrode materials used in SC-SOFC. The most commonly used anode material is cermet with nickel and the electrolyte material and it has been proven to be as a very efficient catalyst for fuel [8-10]. For cathode material, LSM is one of the common cathode materials used in SC-SOFC. However, it is limited to high-temperature applications $\left(>800{ }^{\circ} \mathrm{C}\right)$, at which an acceptable performance can be realized [11]. In addition to LSM, mixed ionic electronic conductors (MIEC) such as SSC, LSCF, BSCF are considered to be an ideal candidate because of their extended triple phase boundaries (TPBs) [12-16]. Our previous work has shed some lights onto the above mentioned materials under methane/air mixture [17]. The result showed that LSM is not suitable for SC-SOFC because of its very high polarization resistance, whereas SCC and BSCF are not stable under single chamber conditions during long time use. LSCF has suitable conductivity and good stability under methane/air mixtures so it seems to be the most promising cathode material in SC-SOFC. Electrolyte is another important component of SC-SOFC. Initially, research in the SC-SOFC is focused on the $\mathrm{Y}_{0.08} \mathrm{Zr}_{0.92} \mathrm{O}_{1.96}$ (YSZ) electrolyte cells [18-20]. However, it requires high operating temperatures to obtain high ionic conductivity, thus resulting in several problems for the cells: undesirable chemical reactions between cell components, aging of components and thermal expansion mismatch, thus accelerating the decrease of the cell performance. To reduce the operating temperature, good ionic conductor such as $\mathrm{La}_{0.8} \mathrm{Sr}_{0.2} \mathrm{Ga}_{0.8} \mathrm{Mg}_{0.2} \mathrm{O}_{3}$ (LSGM) and ceria doped with gadolinium (CGO) or samarium (CSO) are selected as electrolyte materials [21-23]. LSGM is not widely used as electrolyte, because it may present serious chemical reactions with electrodes. CGO or CSO seems to be the most promising electrolyte for SC-SOFC operating at intermediate temperatures $\left(500-700^{\circ} \mathrm{C}\right)$. 
Among the various geometries of SC-SOFC, many investigations have shown that anodesupported cells could provide good performance due to the reducing of the electrolyte thickness and thus the ohmic losses $[19,24,25]$. Anode-supported cells exhibited the highest power output reported so far in SC-SOFC technology [26] and were operated at temperatures down to $200{ }^{\circ} \mathrm{C}$ [27]. Moreover, since a fuel-air mixture gas is always used in SC-SOFCs, it is reasonable to prepare porous thin film electrolyte using low-cost fabrication methods such as screen printing and tape casting. Suzuki et al. prepared a porous YSZ electrolyte film with the thickness of 18 $\mu \mathrm{m}$ on NiO-YSZ anode substrate by screen printing [28]. The open porosity of the YSZ electrolyte film was about $23 \%$. The observed OCV ranged from 680 to $780 \mathrm{mV}$, depending on the gas flow rate at $600^{\circ} \mathrm{C}$. For comparison, a cell with dense film electrolyte showed OCVs of more than $800 \mathrm{mV}$ under the same conditions. The authors described this difference as due to the diffusing of the formed hydrogen and $\mathrm{CO}$ from the anode to the cathode through the porous electrolyte. Nevertheless, the peak power density reached about 200 and $600 \mathrm{~mW} \mathrm{~cm}^{-2}$ at gas flow rate of 300 and $900 \mathrm{ml} \mathrm{min}^{-1}$, respectively. In our previous work, the anode-supported fuel cells were prepared with NiO-CGO anode pellets, screen printed CGO electrolytes and LSCFCGO (LSCF/CGO=70/30) composite cathode. The thicknesses of the obtained porous film electrolyte were varied from $20 \mu \mathrm{m}$ to $50 \mu \mathrm{m}$ respectively. At $600^{\circ} \mathrm{C}$ for $\mathrm{R}_{\mathrm{mix}}=0.6$, the maximum power density was improved from 60 to $160 \mathrm{~mW} \mathrm{~cm}^{-2}$ [29].

Because of the complexity of the SC-SOFC, it is difficult to make a reasonable comparison with the reported results in the literature due to the discrepancy in materials, testing conditions and even cell dimensions (e.g electrode size). To further optimize the performance of the cell in our testing bench conditions, we present the recent results concerning anode-supported SC-SOFC with CGO electrolyte, Ni-CGO anode and LSCF-CGO cathode. In this study, a dense electrolyte 
is prepared through a dry-pressing/sintering process. The performance of the cell was compared with the one in previous work using porous electrolyte. The cathode composition, sintering parameters and testing conditions were also optimized to obtain a peak power density.

\section{Experimental}

\subsection{Materials and Cell Preparation}

All the materials used in the fuel cells are commercial powders from Fuel Cell Materials.

Gadolinium doped ceria $\mathrm{Ce}_{0.9} \mathrm{Gd}_{0.1} \mathrm{O}_{2-\delta}(\mathrm{CGO})$ is used for the electrolyte, and also as one component in electrodes. $\mathrm{La}_{0.6} \mathrm{Sr}_{0.4} \mathrm{Co}_{0.2} \mathrm{Fe}_{0.8} \mathrm{O}_{3-\delta}$ (LSCF) and $\mathrm{NiO}$ powders are selected as another composition in the electrodes.

The fuel cell employed in this study is in anode-supported thin-film electrolyte configuration. The anode powder is a mixture of $\mathrm{NiO}(60 \mathrm{wt} \%)$ and $\mathrm{CGO}(40 \mathrm{wt} \%)$. A dry-pressing/sintering method was adopted in order to fabricate the anode-supported CGO bi-layer pellets. These green dual-layer pellets resulting from dry pressing were fired first at $500{ }^{\circ} \mathrm{C}$ for $2 \mathrm{~h}$, and then at 1200 ${ }^{\circ} \mathrm{C}$ for $4 \mathrm{~h}, 1400{ }^{\circ} \mathrm{C}$ for additional $2 \mathrm{~h}$ in air, to achieve the densification of the electrolyte layer and good connection between the dual layers. The thickness of the electrolyte is controlled by adding different amount of CGO powders during pressing. The cathode powders (LSCF + CGO) with different compositions (50:50, 60:40, 70:30, and 80:20 wt\%) were first mixed with a binder (ESL V400, 0.5g per gram of powder) and solvent (ESL T404, eight drops per gram of powder) and then homogenized and disagglomerated in a rolling mill. The resulting ink was screenprinted on the electrolyte surface of the fresh dual-layer membranes, and then calcined at $1000^{\circ} \mathrm{C}$, $1050{ }^{\circ} \mathrm{C}$ and $1100{ }^{\circ} \mathrm{C}$ for $2 \mathrm{~h}$, respectively. Three cathodes with effective geometric surface area of $0.36,0.95$ and $2.27 \mathrm{~cm}^{2}$ respectively were prepared in order to evaluate the influence of the 
electrode area on the cell's power density. Finally, a gold mesh was screen-printed on the cathode with a commercial gold ink (ESL 8880-H) as the current collector. The typical thickness of the obtained anode-supported SC-SOFCs is about $1 \mathrm{~mm}$ for anode, $150 \mu \mathrm{m}$ for electrolyte and $30 \mu \mathrm{m}$ for cathode.

\subsection{Fuel cell performance test}

The experimental set up is similar to the one that is described elsewhere [29]. An in situ reduction mode of the anode is employed in this work according to the findings by D. Rembelski et al. [29]. Generally before electrochemical performance test, $10 \%$ methane diluted in nitrogen (10:90) is introduced into the reactor for $3 \mathrm{~min}$ and then switched to a mixed atmosphere of $\mathrm{CH}_{4^{-}}$ $\mathrm{O}_{2}-\mathrm{N}_{2}(20: 10: 70)$ with $\mathrm{R}_{\text {mix }}=2$ for $15 \mathrm{~min}$ at $700{ }^{\circ} \mathrm{C}$, to get the fully reduction of the $\mathrm{NiO}$ in the anode. The performances of the single cell are measured at furnace temperature between 500 and $600{ }^{\circ} \mathrm{C}$. The ratio of methane to oxygen $\left(\mathrm{R}_{\text {mix }}\right)$ is varied from 0.6 to 2.0 as controlled by mass flow controllers (BROOKS Smart II Mass Flow).

For all the experiments performed in methane/air/nitrogen mixtures, oxygen is fixed at $10 \%$ (V/V) in order to avoid the flammability area of methane. The total gas flow is set at $30 \mathrm{~L} \mathrm{~h}^{-1}$ for cells test.

\subsection{Characterization}

The microstructures of the electrode and electrolyte were characterized using a scanning electron microscope (SEM, JEOL JSM-6500).

For the measurement of electrochemical properties, gold wire and gold mesh were applied as current collectors on both sides of the complete fuel cells. Polarization curves were obtained using a 4-probe technique with Keithley 2400 to eliminate the effect of the wire resistances. Two 
identical cells were prepared and measured separately. Each measurement was repeated three times and the mean value was used to evaluate the cell performance.

\section{Results and discussions}

\subsection{Microstructure of the cell}

Figure 1 shows the detail micrographs of the SC-SOFC after the measurements in the methane and oxygen mixed atmospheres. Obviously the cross-section of the cell consists of three layers, the Ni-CGO cermet anode, the CGO electrolyte and the LSCF-CGO (LSCF/CGO=70/30) composite cathode (Fig.1a). The thickness of the electrolyte is about $150 \mu \mathrm{m}$, and the cathode is about $30 \mu \mathrm{m}$. The electrodes are well adhered on the electrolyte surface. Fig.1b, $\mathrm{c}$ and d show the magnified view of the electrolyte, surface of the cathode and anode, respectively. It is observed that the CGO electrolyte prepared by dry pressing method exhibits a dense microstructure after sintered at $1400^{\circ} \mathrm{C}$ for 2 hours (Fig. 1b). The morphology of LSCF powders is irregular with some agglomeration. The particle size are about 2-3 $\mu \mathrm{m}$ and the CGO particles are about 300400nm, which are dispersed homogeneously on the LSCF particle surface (Fig. 1c). For the anode that is sintered at $1400{ }^{\circ} \mathrm{C}$ for 2 hours, a microstructure with moderate porosity and wellnecked particles was formed (Fig. 1d). The mean particle size is about $1 \mu \mathrm{m}$ and slight aggregation of the particles was observed.

\subsection{Performance of the cell}

\subsubsection{The effect of the electrolyte thickness}

The test cells with cathode area of $0.36 \mathrm{~cm}^{2}$ were investigated to optimize the electrolyte thickness. Figure 2 shows the I-V and I-P curves of the SC-SOFC cells. The measurement was performed at $600{ }^{\circ} \mathrm{C}$ under a mixing gas of $\mathrm{R}_{\mathrm{mix}}=2$. The $\mathrm{OCV}$ was found to remain about $0.88 \mathrm{~V}$ 
and no significant change is observed, but the power density decreased dramatically with the increase of CGO thickness from $150 \mu \mathrm{m}$ to $300 \mu \mathrm{m}$. The maximum power density of $260 \mathrm{~mW}$ $\mathrm{cm}^{-2}$ was obtained at CGO thickness of $150 \mu \mathrm{m}$. As the thickness increased to 230 and $300 \mu \mathrm{m}$, the maximum power density decreased to 178 and $162 \mathrm{~mW} \mathrm{~cm}^{-2}$, respectively. As it is expected, the improvement of the SOFC performance is due to the reduction of electrolyte ohmic loss. Currently, it is difficult to obtain an electrolyte thinner than $150 \mu \mathrm{m}$ using the dry-pressing method. Therefore, in the following work, the thickness of the electrolyte was fixed at $150 \mu \mathrm{m}$ and the influence of the cathode microstructure on the cell performance is further investigated.

\subsubsection{The effect of the cathode sintering temperatures}

It is well known that sintering temperature has remarkable influence on the microstructure of the electrode, which in turn has remarkable effects on the cell performance. There are two microstructure factors that govern the cell performance. One of them is the connectivity of the electrode particles. Obviously a well-developed connection among electrode particles will pave the way for electrons and oxygen ions that pass through the electrode and electrode/electrolyte interface. Porosity is another important factor, as the pores facilitate the gas diffusion and at the same time increase the number of active reaction sites. The effects of sintering temperatures on the output of cells are compared in Fig. 3. It can be seen, the power density increases with the sintering temperature of the cathode. The best performance is obtained when the sintering temperature of LSCF-CGO cathode is $1100{ }^{\circ} \mathrm{C}$. This result can be explained by the microstructure evolution of LSCF-CGO cathodes with sintering temperature (Fig.4). A loose agglomerated feature with inhomogeneous porous structure has been observed in the LSCF-CGO cathodes that were sintered at low temperatures such as 1000 and $1050{ }^{\circ} \mathrm{C}$. The weak connection between particles increases the resistance of bulk/surface diffusion of oxygen species as well as 
electron transfer through the porous cathode. After sintering at $1100{ }^{\circ} \mathrm{C}$ for two hours, a microstructure with good connection between the electrode particles and moderate porous structure can be observed and thus results in the improved cell performance.

\subsubsection{The effect of the cathode thickness}

Three cells with respectively one, two and three layers cathode sintered at $1100{ }^{\circ} \mathrm{C}$ were prepared by screen printing method. The effect of cathode thickness on the cell performance at different current densities was investigated. The optimal power density was obtained for the cell with two layers cathode (Fig.5). Further increase of the cathode thickness leads to the rapid decreaced of performance. Figure 6 gives the cross-section micrograph of the cells with one and two cathode layers after the test in the SC-SOFC measurement system. It can be seen that the thickness of one and two layers are about $15 \mu \mathrm{m}$ and $30 \mu \mathrm{m}$, respectively. Unfortunately, the cathode with three layers was peered off after the test. Considering the good repeatability of screen-printing technique, we propose that the thickness of the three layers cathode is about $45 \mu \mathrm{m}$. Considering the combined effect of the number of reaction active site (RAS, which is propotional to the cathode thickness) and the gas diffusion depth in the porous cathode, a cathode with suitable thickness must ensure enough RAS, and at the same time to make sure that the reaction gas can penetrate through the cathode. With the increase of the cathode thickness however, the ohm resistance of the cathode increases, and the gas diffusion becomes difficult [30]. The combined effects result in optimized cell performance when the cathode thickness is $\sim 30 \mu \mathrm{m}$.

\subsubsection{The effect of cathode composition}

Figure 7 shows the OCV and power density of the cells with various cathode compositions as a function of current density. The power density increases with the CGO content, reaches a maximum at $30 \mathrm{wt} \%$ CGO, and then decreases with the further increase of CGO content. The 
OCV is about $0.9 \mathrm{~V}$ and shows no dependance on the CGO composition. The effect of CGO contents on cell performance can be understood, considering the catalytic properties of the composite cathode. An increase of CGO content in LSCF may provide additional oxygen ions transfer path in the composite cathode, which inturn reduce the ion transfer resistance and improve the oxygen reduction reaction (ORR) [31-33]. An further increase of CGO content however will interrupt the connection between the LSCF particles and decrease the conductivity [34]. As a result, the performance begin to decrease as the CGO content is over 30wt $\%$ in the composite cathode.

\subsubsection{The effect of testing temperature}

The working temperature has significant effect on the cell performance. In the case of CGO electrolyte, for $\mathrm{T}>700{ }^{\circ} \mathrm{C}$, a sizeable electronic conductivity takes place. This causes a decrease of the OCV, thus reduce the power density. Considering these factors, a moderate testing temperature range $500-600^{\circ} \mathrm{C}$ was chosen. In our experiment, the testing temperature refers to the furnace temperature $\left(\mathrm{T}_{\mathrm{f}}\right)$. Due to the exothermic effect of methane oxidation reaction, as reported by Rembelski et al. [29] and Hibino and al. [35], the actual temperature on the electrode $\left(T_{e}\right)$ is different from $T_{f}$. Fig. 8 shows overheat temperatures $\left(\Delta T=T_{e}-T_{f}\right)$ on the anode cermet side and cathode side for different $\mathrm{R}_{\text {mix }}$ gas system at set (furnace) temperatures. A $35-50{ }^{\circ} \mathrm{C}$ overheating is found for anode cermet as shown in Fig.8a. At high temperatures (above $550{ }^{\circ} \mathrm{C}$ ), the tendency of increasing overheat temperature with $\mathrm{R}_{\text {mix }}$ is maintained. The overheating effect on cathode in Fig. 8b is smaller than that on cermet anode, and exhibits opposite tendency with $\mathrm{R}_{\text {mix }}$ above $550{ }^{\circ} \mathrm{C}$. At $500{ }^{\circ} \mathrm{C}$, the $\Delta \mathrm{T}$ on the cermet and cathode exhibits no obvious change with $\mathrm{R}_{\text {mix }}$. 
The influence of the test temperature on the cell performance is shown in Fig.9. It can be observed that the maximum power density increases from 121 to $260 \mathrm{~mW} \mathrm{~cm}^{-2}$ as the furnace temperature increases from 500 to $600{ }^{\circ} \mathrm{C}$. At the same time, there is an apparent decrease in the OCV with the increase of the temperature. At $500{ }^{\circ} \mathrm{C}$ an OCV of $0.94 \mathrm{~V}$ can be obtained. Upon raising the furnace temperature to $600{ }^{\circ} \mathrm{C}$, the $\mathrm{OCV}$ decreases to $0.88 \mathrm{~V}$. This is due to the deteriorated selectivity of the electrodes and the promoted catalytic activity of the cathode towards methane chemical oxidation reaction with the increase temperatures.

\subsubsection{The effect of gas composition}

The effect of gas composition on the cell performance was studied under different operating temperatures from $500-600{ }^{\circ} \mathrm{C}$. Fig. 10 shows the typical discharge profile of the cell prepared in optimal conditions and tested at furnace temperature of $600{ }^{\circ} \mathrm{C}$ under different ratios of methane to oxygen. A common trend has been observed in which $\mathrm{R}_{\operatorname{mix}}=2$ gives the best and $\mathrm{R}_{\operatorname{mix}}=0.6$ gives the worst cell performance. The similar results were obtained at $550{ }^{\circ} \mathrm{C}$ and $500{ }^{\circ} \mathrm{C}$. The influence of the gas composition on the OCV is presented in Figure 11 . At $500{ }^{\circ} \mathrm{C}$, the OCV is almost unchanged with $\mathrm{R}_{\text {mix }}$. With the increase of the temperature, a tendency of slight increase of OCV with $R_{\text {mix }}$ can be observed. The maximum value of $O C V$ is obtained at $R_{\text {mix }}=2$, independent on furnace temperatures. As we know, $R_{\text {mix }}=2$ corresponds to the stoichiometric composition of the gas mixture for the partial oxidation of methane according to the following reaction:

$\mathrm{CH}_{4}+1 / 2 \mathrm{O}_{2} \rightarrow 2 \mathrm{H}_{2}+\mathrm{CO}$

This reaction is expected to occur on the anode catalyst followed by the complete electrooxidation of the syngas $\left(\mathrm{H}_{2}+\mathrm{CO}\right)$. With the decrease of $\mathrm{R}_{\text {mix }}$, the oxygen-rich mixture will enhance the non-electrochemical combustion of methane, reduce the oxygen partial pressure 
differential between the electrodes and hence the OCV. Similarly, fuel-rich mixtures will decrease the oxygen partial pressure at the cathode and therefore the cell voltage. Our observation (maximum OCV values appear at $\mathrm{R}_{\text {mix }}=2$ ) is consistent with previous studies of anode-supported SC-SOFCs including Ni-La $\mathrm{L}_{0.75} \mathrm{Sr}_{0.25} \mathrm{Cr}_{0.5} \mathrm{Fe}_{0.5} \mathrm{O}_{3-\delta^{-}} \mathrm{YSZ} / \mathrm{YSZ} / \mathrm{LSM}$ cells [36], Ni-YSZ/YSZ/LSM cells [19, 37], $\mathrm{Pd}-\mathrm{Ce}_{0.8} \mathrm{Sm}_{0.2} \mathrm{O}_{1.9}-\mathrm{Ni} / \mathrm{Ce}_{0.8} \mathrm{Sm}_{0.2} \mathrm{O}_{1.9} / \mathrm{Sm}_{0.5} \mathrm{Sr}_{0.5} \mathrm{CoO}_{3}$ cells [10], and Ni-YSZ/YSZ/LSM-SDC cells [38]. This result is contrast to some reports in the literature where the porous electrolyte was used in SC-SOFCs [29]. It was proposed that the diffusion of hydrogen from the anode to the cathode through the pores electrolyte could lower the oxygen partial pressure at the cathode side and thus decrease the OCV. Therefore in their cases, OCV increases when $\mathrm{R}_{\operatorname{mix}}$ is reduced because of less hydrogen diffusion.

\subsubsection{The effect of cathode area}

Another important factor that has dramatic effect on the cell performance is the area ratio of cathode to anode. However few researchers take into account of this factor in the literature. Chung and al. and Suzuki et al. reported that using a cathode with a geometric area significantly less than that of the anode can enhance the power density $[39,40]$. To illustrate the effect of cathode area, several test cells with different area ratio of cathode to anode have been prepared. The anode area is fixed at $2.83 \mathrm{~cm}^{2}$ and the cathode area (S) was $0.36 \mathrm{~cm}^{2}, 0.95 \mathrm{~cm}^{2}$ and 2.27 $\mathrm{cm}^{2}$, respectively. The ratio of cathode area to anode area $\left(\mathrm{r}_{\mathrm{c}} / \mathrm{r}_{\mathrm{a}}\right)$ is $0.13,0.34$ and 0.80 . As it can be seen in Fig.12, the power density increases gently with the decrease of $r_{c} / r_{a}$. The peak power density varies from $260 \mathrm{~mW} \mathrm{~cm}^{-2}$ to $210 \mathrm{~mW} \mathrm{~cm}^{-2}$ when the cathode area increases from 0.36 $\mathrm{cm}^{2}$ to $2.27 \mathrm{~cm}^{2}$. This result is consistent with the relevant research of Chung et al. and Suzuki et al., but less severely attenuation of the power density was found in our cells as that observed in literature $[39,40]$. This can be attributed to the well optimized processing technology and the 
careful control of electrode microstructure, thus the effect of the area ratio on the normalized power density enhancement is less pronounced. Considering the real application in a stack, the area ratio of the cathode to anode should be as closer as to 1 . Further comparison was made with our previous work using the $r_{c} / r_{a}=0.80$. In the previous work, a test cell was prepared with porous electrolyte in $50 \mu \mathrm{m}$ thickness (with cathode area $2.27 \mathrm{~cm}^{2}$ ), and the peak power density reached $160 \mathrm{~mW} \mathrm{~cm}^{-2}$ at $600^{\circ} \mathrm{C}$ for $\mathrm{R}_{\text {mix }}=0.6$. The current result shows an increase of $50 \mathrm{~mW}$ in the power density and the $\mathrm{OCV}$ improves from $0.67 \mathrm{~V}$ to $0.88 \mathrm{~V}$. Although it is not obliged to use densified electrolyte in SC-SOFC (as it is always to be high-lighted as one of the merits in SCSOFC), our result indicates that the electrolyte density is beneficial for improving the cell performance. This may be due to the improved ion conductivity in the densified electrolyte and at the same time the blocking effect of the direct diffusion of syngas from anode to cathode. Further decrease in the thickness of the electrolyte in current cell would lead to much promising results.

\section{Conclusions}

Anode-supported fuel cells with NiO-CGO (60:40 wt\%) anode, CGO electrolyte and LSCFCGO cathode were fabricated and tested under methane-air mixtures. Preparation condition of the cathode, electrolyte thickness, and testing conditions were found to play strong roles in fuel cells overall behavior. In this work, the best processing condition is LSCF-CGO (70:30 wt\%) cathode with $30 \mu \mathrm{m}$ thickness and sintered at $1100{ }^{\circ} \mathrm{C}$ for $2 \mathrm{~h} . \mathrm{A} \mathrm{R}_{\text {mix }}=2$ gas mixture leads to improved performance and the maximum power density is $260 \mathrm{~mW} \mathrm{~cm}^{-2}$ at $600{ }^{\circ} \mathrm{C}$. Electrolyte thickness is another important parameter for the SC-SOFC. The maximum power density 
increases from $162 \mathrm{~mW} \mathrm{~cm}^{-2}$ to $260 \mathrm{~mW} \mathrm{~cm}^{-2}$ when the electrolyte thickness decreases from $300 \mu \mathrm{m}$ to $150 \mu \mathrm{m}$.

\section{Acknowledgement:}

The project was supported by La Région Rhône-Alpes "CMIRA 2012 Accueil Pro” and National Natural Science Foundation of China (51302069 and 51372073), Natural Science foundation of Heilongjiang Province in China (JC201211, B201107).

\section{References}

[1] Yano M, Tomita A., Sano M, Hibino T. Recent advances in single-chamber solid oxide fuel cells: a review. Solid State Ionics 2007; 177: 3351-9.

[2] Zhang C, Lin Y, Ran R, Shao Z. Improving single chamber performance of an anodesupported SOFC by impregnating anode with active nickel catalyst. Int. J. Hydrogen Energy 2010; 35: 8171-6.

[3] Liu ML, Lü Z, Wei B, Huang XQ, Zhang YH, Su WH. Effects of the single chamber SOFC stack configuration on the performance of the single cells. Solid State Ionics 2010; 181: 939-42. [4] Akhtar N, Kendall K. Silver modified cathode for a micro-tubular, single-chamber solid oxide fuel cell. Int. J. Hydrogen Energy 2011; 36: 773-8.

[5] Wei B, Lü Z, Huang XQ, Liu ML, Jia DC, Su WH. A novel design of single-chember SOFC micro-stack operated in methane-oxygen mixture. Electrochem. Commun. 2009; 11: 347-50. [6] Masaya Y, Masahiro N, Kohsuke O, Atsuko T, Yasuyuki U, Naoki U, Takashi H. A singlechamber SOFC stack operating in engine exhaust. Electrochem. Solid-State Lett, 2008; 11: B2933. 
[7] Shao ZP, Zhang C, Wang W, Su C, Zhou W, Zhu ZH, Park HJ, Kwak C. Electric power and synthesis gas Co-generation from methane with zero waste gas emission. Angew. Chem. Int. Ed. 2011; 50: 1792-7.

[8] Van R LN, Le J, Van RC, Schoonman J. A novel Ni-Cermet electrode based on a proton conducting electrolyte. J. Mater.Sci. 2001; 36: 1069-76.

[9] Larrondo SA, Kodjaian A, Fabregas I, Zimicz MG, Lamas DG, Walsoe BE, Amadeo NE. Methane partial oxidation using $\mathrm{Ni} / \mathrm{Ce}_{0.9} \mathrm{Zr}_{0.1} \mathrm{O}_{2}$ catalysts. Int. J. Hydrogen Energy 2008; 33: $3607-13$.

[10] Hibino T, Hashimoto A, Yano M, Suzuki M, Yoshida SI, Sana MA. High performance anodes for SOFCs operating in methane-air mixture at reduced temperatures. J. Electrochem. Soc. 2002; 149: A133-6.

[11] Jasinski P, Suzuki T, Zhou XD, Dogan F, Anderson HU. Single chamber solid oxide fuel cell-investigation of cathodes. Ceram. Eng. Sci. Proc. 2003; 24: 293-8.

[12] Ruiz de Larramendi I, Lamas DG, Gabezas MD, Ruiz de Larramendi JI, Walsöe de Reca NE, Rojo T. Development of electrolyte-supported intermediate-temperature single-chamber solid oxide fuel cells using $\mathrm{Ln}_{0.7} \mathrm{Sr}_{0.3} \mathrm{Fe}_{0.8} \mathrm{Co}_{0.2} \mathrm{O}_{3-\delta}(\mathrm{Ln}=\mathrm{Pr}, \mathrm{La}, \mathrm{Gd})$ cathodes. J. Power Sources, 2009; 193:774-8.

[13] Hibino T, Hashimoto A, Inoue T, Tokuno JI, Yoshida SI, Sano MA. A low-operating temperature solid oxide fuel cell in hydrocarbon-air mixtures. Science, 2000; 288: 2013-33. [14] Shao Z, Haile SM. A high-performance cathode for the next generation of solid oxide fuel cells, Nature, 2004; 431: 170-3. 
[15] Kuhn M, Napporn TW, Meunier M, Therriault D. Single-chamber micro solid oxide fuel cells: Study of anode and cathode materials in coplanar electrode design. Solid State Ionics 2010; 181: 332-7.

[16] Song HS, Min JH, Kim J, Moon J. Phase stability of $\mathrm{Sm}_{0.5} \mathrm{Sr}_{0.5} \mathrm{CoO}_{3}$ cathodes for on-planar type, single chamber, solid oxide fuel cells. J. Power Sources 2009; 191: 269-74.

[17] Rembelski D, Viricelle JP, Combemale L, Rieu M. Characterization and comparison of different cathode materials for SC-SOFC: LSM, BSCF, SSC, and LSCF. Fuel Cells 2012; 12: $256-64$.

[18] He F, Sun LP, Huo LH, Zhao H, Pijolat C. Electrochemical properties of cathode material $\mathrm{La}_{0.75} \mathrm{Sr}_{0.25} \mathrm{Mn}_{0.5} \mathrm{Mn}_{0.5} \mathrm{O}_{3}$ for single chamber solid oxide fuel cell 9SC-SOFC). Chin. J. Inorg. Chem. 2011; 27: 281-6.

[19] Jacques-Bédard X, Napporn TW, Roberge R, Meunier M. Performance and ageing of an anode-supported SOFC operated in single-chamber conditions. J. Power Sources; 2006, 153:10813

[20] Hibino T, Wang SQ, Kakimoto S, Sano M. Single chamber solid oxide fuel cell constructed from an Yttria-Stabilized Zirconia electrolyte. Electrochem. Solid-State Lett, 1999; 2: 317-9. [21] Hibino T, Hashimoto A, Inoue T, Tokuno JI, Yoshida SI, Sano M. Singel-chamber solid oxide fuel cells at intermediate temperatures with vatious hydrocarbon-air mixtures. J. Electrochem. Soc. 2000; 147: A2888-92.

[22] Morales M, Roa JJ, Tartaj J, Segarra M. Performance and short-term stability of singlechamber solid oxide fuel cells based on $\mathrm{La}_{0.9} \mathrm{Sr}_{0.1} \mathrm{Ga}_{0.8} \mathrm{Mg}_{0.2} \mathrm{O}_{3-\delta}$ electrolyte. J. Power Sources 2012; 216: 417-24. 
[23] Morales M, Pinol S, Segarra M. Intermediate temperature single-chamber methane fed SOFC based on Gd doped ceria electrolyte and $\mathrm{La}_{0.5} \mathrm{Sr}_{0.5} \mathrm{CoO}_{3-\delta}$ as cathode. J. Power Sources 2009; 194: 961-6.

[24] Ai G, Lü Z, Wei B, Huang XQ, Chen KF, Su WH. Performance of anode-supported singlechamber solid oxide fuel cells. Chin. J. Catal. 2006; 27: 885-9.

[25] Piñol S, Morales M, Espiell F. Low temperature anode-supported solid oxide fuel cells based on gadolinium doped ceria electrolytes. J. Power Sources 2007; 169: 2-8.

[26] Shao Z, Mederos J, Chueh WC, Haile SM. High power-density single-chamber fuel cells operated on methane. J. Power Sources 2006; 162: 589-96.

[27] Tomita A, Hirabayashi D, Hibino T, Nagao M, Sano M. Single-chamber SOFCs with a $\mathrm{Ce}_{0.9} \mathrm{Gd}_{0.1} \mathrm{O}_{1.95}$ electrolyte film for low-temperature operation. Electrochem. Solid-State Lett. 2005, 8: A63-5.

[28] Suzuki T, Jasinski P, Petrovsky V, Anderson HU, Dogan F. Performance of a porous electrolyte in single-chamber SOFCs. J. Electrochem. Soc. 2005; 152: A527-31.

[29] Rembelski D, Rieu M, Combemale L, Viricelle JP. In situ reduction and evaluation of anode supported single chamber fuel cells. J. Power Sources 2013; 242: 811-6.

[30] Kivi I, Drovtar I, Anderson E, Aruväli J, Tammc K, Gunnar N, Möller P, Vestli M, Kanarbik R, Lust E. Influence of cathode thickness on the oxygen reduction kinetics at the intermediate temperature SOFC cathodes, ECS Trans. 2011; 35: 2349-55.

[31] Perry Muffay E, Sever MJ, Barnett SA. Electrochemical performance of $(\mathrm{La}, \mathrm{Sr})(\mathrm{Co}, \mathrm{Fe}) \mathrm{O}_{3^{-}}$ $\mathrm{Ce}, \mathrm{Gd}) \mathrm{O}_{3}$ composite cathodes. Solid States Ionics 2002; 148: 27-34.

[32] Dusastre V, Kilner JA. Optimization of composite cathodes for intermediate temperature SOFC applications. Solid States Ionics 1999; 126: 163-74. 
[33] Qiang F, Sun KN, Zhang NQ, Zhu XD, Le SR, Zhou DR. Characterization of electrical properties of GDC doped A-site deficient LSCF based composite cathode using impedance spectroscopy. J. Power Sources, 2007; 168: 338-45.

[34] Leng YJ, Chan SH, Liu QL. Development of LSCF-CGO composite cathodes for lowtemperature solid oxide fuel cells with thin film GDC electrolyte. Int. J. Hydrogen Energy 2008; 33: $3808-17$.

[35] Hibino T, Hashimoto A, Inoue T, Tokuno J, Yoshida S, Sano M. A Solid oxide fuel cell using an exothermic reaction as the heat source. J. Electrochem. Soc. 2001; 148: A544-9. [36] Zhu XB, Lü Z, Wei B, Zhang YH, Huang XQ, Su WH. Fabrication and evaluation of a $\mathrm{Ni} / \mathrm{La}_{0.75} \mathrm{Sr}_{0.25} \mathrm{Fe}_{0.5} \mathrm{O}_{3-\delta}$ co-impregnated yttria-stabilized zirconia anode for single-chamber solid oxide fuel cells. Int. J. Hydrogen Energy 2010; 35: 6897-904.

[37] Napporn TW, Jacques-Bedard X, Morin F, Meunier M. Operation conditions of a singlechamber SOFC. J. Electrochem. Soc. 2004; 151: A2088-94.

[38] Wei B, Lü Z, Huang XQ, Liu ML, Chen KF, Su WH. Enhanced performance of a singlechamber solid oxide fuel cell with an SDC-impregnated cathode. J. Power Sources, 2007; 167: $58-63$.

[39] Chung BW, Pham AQ, Haslam JJ, Glass RS. Influence of electrode configuration on the performance of electrode-supported solid oxide fuel cells, J. Electrochem. Soc. 2002; 149: A32530.

[40] Suzuki T, Jasinski P, Petrovsky V, Anderson HU, Dogan F. Anode supported single chamber solid oxide fuel cell in $\mathrm{CH}_{4}$-Air mixture. J. Electrochem. Soc. 2004; 151: A1473-6. 


\section{Figure captions}

Fig. 1: SEM images of cross-section view of Ni-CGO/CGO/LSCF-CGO cell (a), magnified CGO electrolyte (b), surface of the LSCF-CGO cathode (c) and surface of the Ni-CGO anode (d).

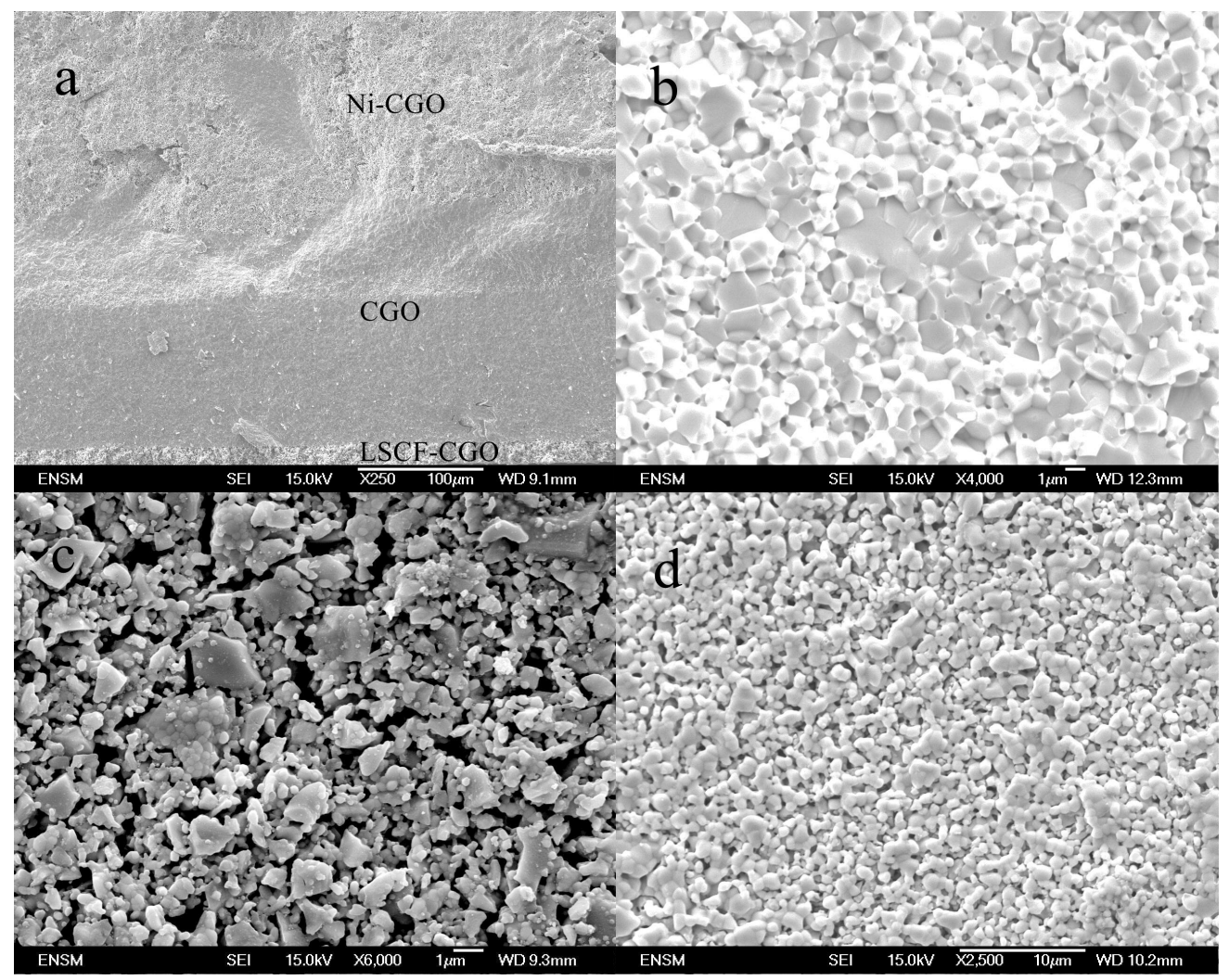


Fig. 2: I-V and I-P curves for cells with different thickness of electrolyte test at $600{ }^{\circ} \mathrm{C}$ for $\mathrm{R}_{\operatorname{mix}}=2$.

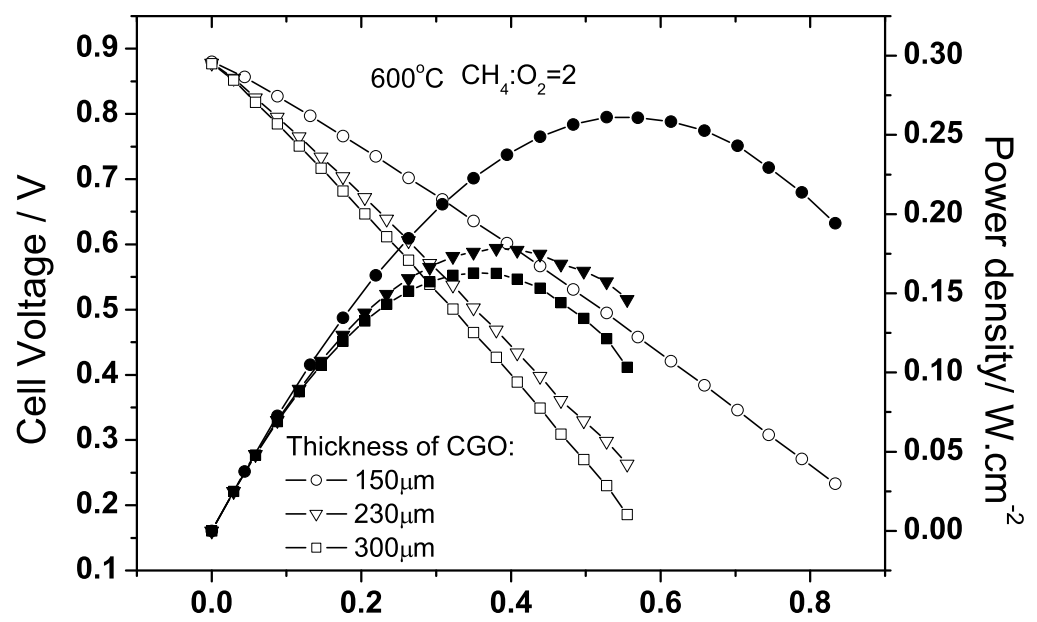

Current density / A.cm ${ }^{-2}$

Fig. 3: I-V and I-P curves at $600{ }^{\circ} \mathrm{C}$ under a $\mathrm{CH}_{4} /$ air mixture with a $\mathrm{CH}_{4}: \mathrm{O}_{2}$ ratio of 2:1 for cells with LSCF-CGO cathodes sintered at different temperatures.

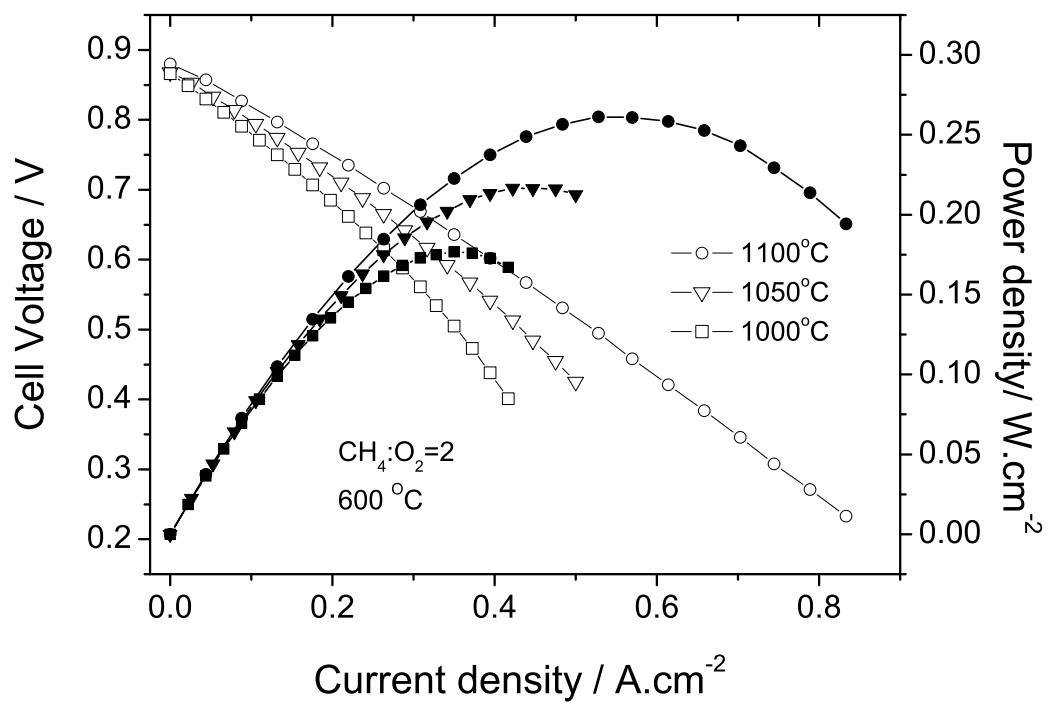


Fig. 4: SEM images of top-view of LSCF-CGO composite cathode sintered at different temperatures for 2 hours: (a) $1000{ }^{\circ} \mathrm{C}$, (b) $1050{ }^{\circ} \mathrm{C},(\mathrm{c}) 1100{ }^{\circ} \mathrm{C}$.

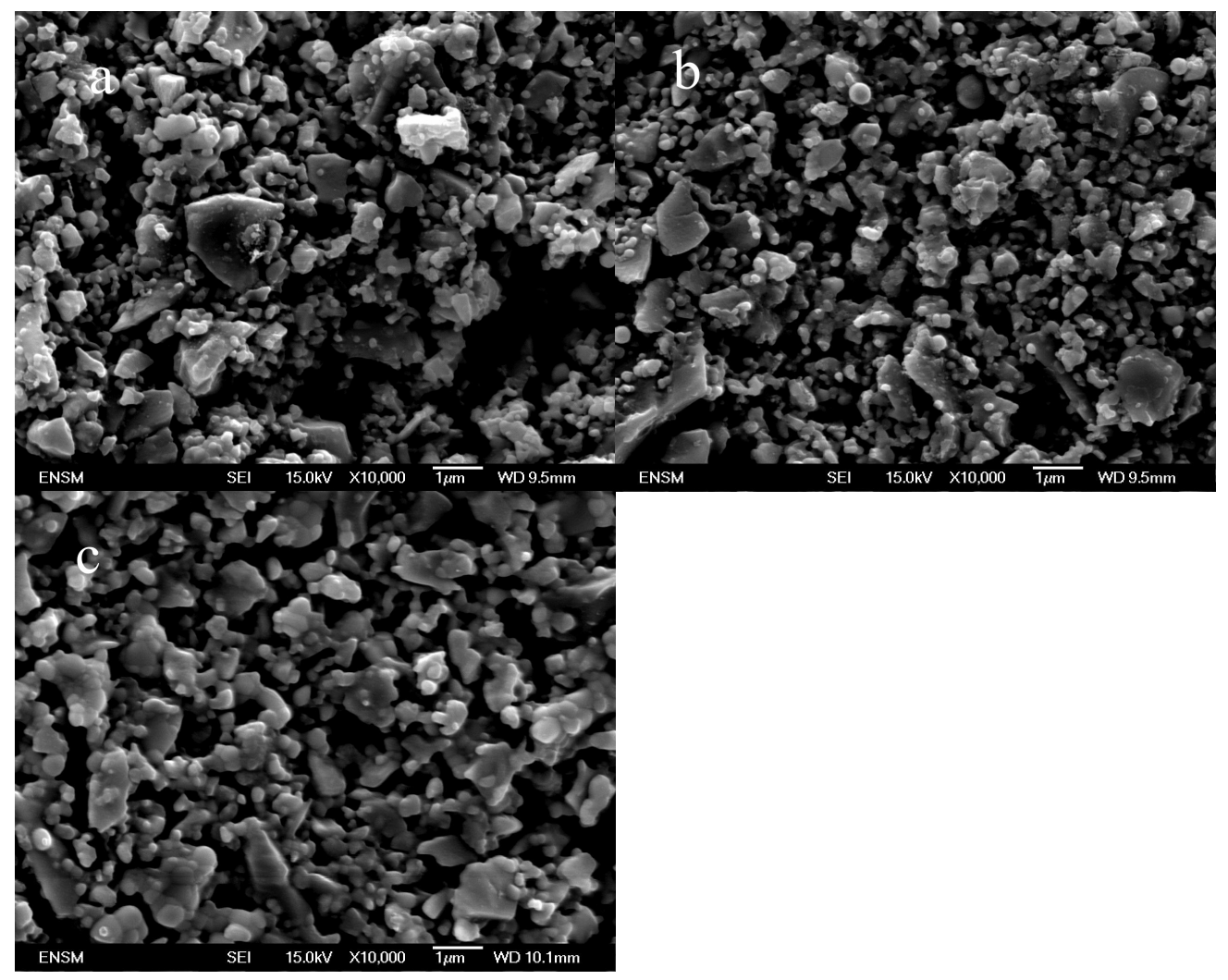


Fig. 5: I-V and I-P curves at $600{ }^{\circ} \mathrm{C}$ under a $\mathrm{CH}_{4} /$ air mixture with a $\mathrm{CH}_{4}: \mathrm{O}_{2}$ ratio of 2:1 for cells with LSCF-CGO cathodes with different thickness.

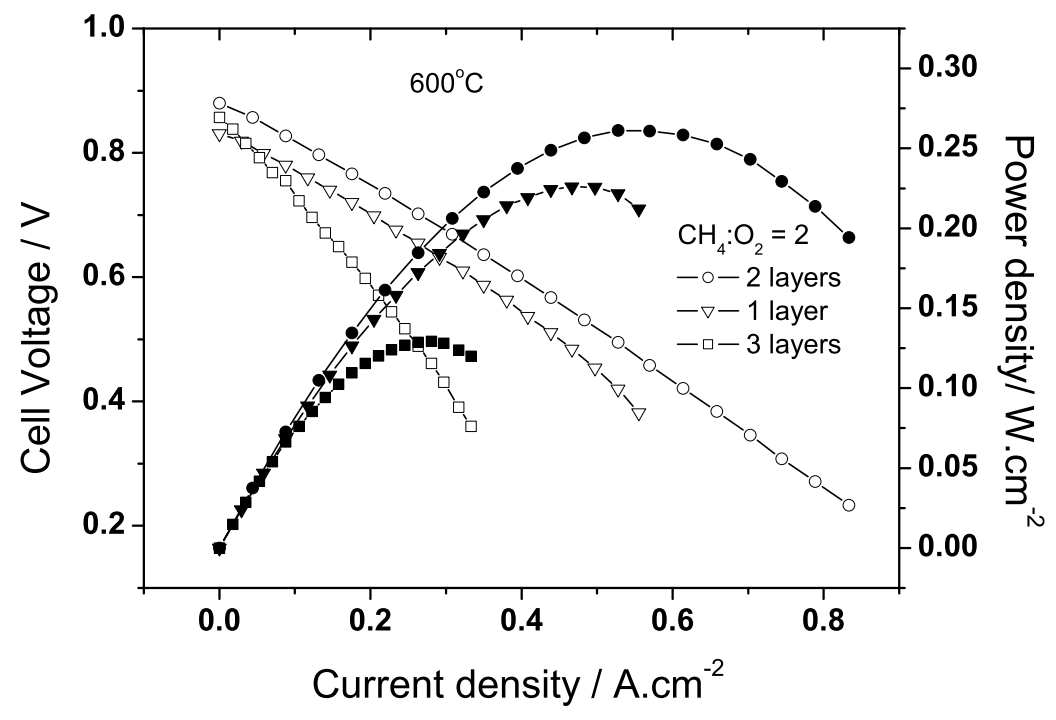

Fig. 6: SEM images of cross-section of the LSCF-CGO composite cathode with different layers: (a) one layer, (b) two layers.

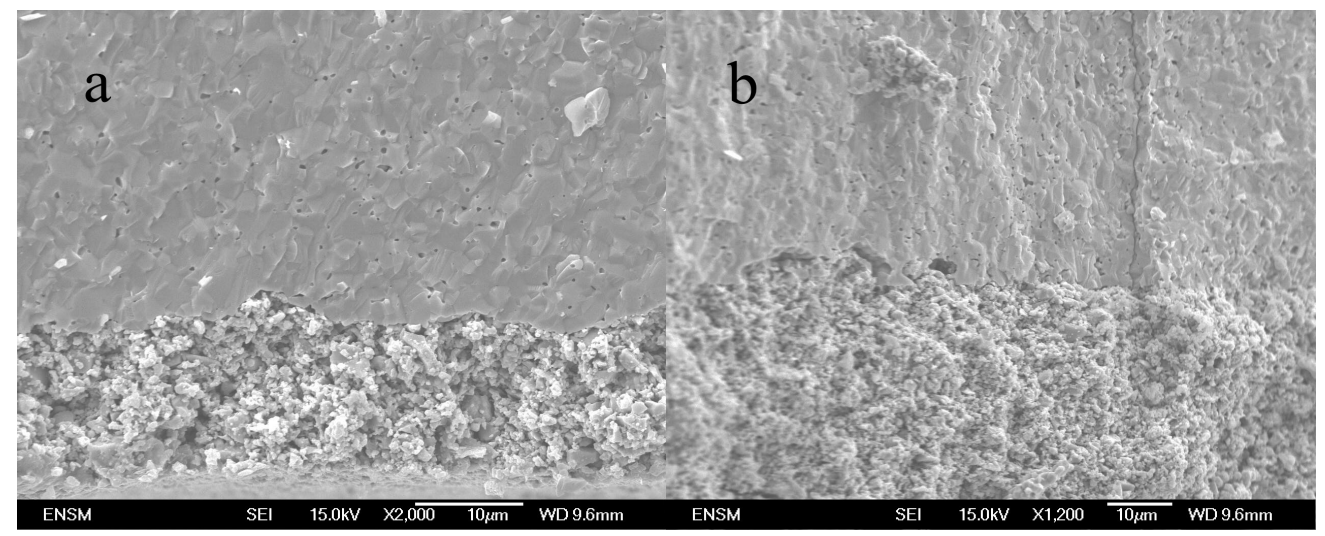


Fig. 7: I-V and I-P curves at $600{ }^{\circ} \mathrm{C}$ under a $\mathrm{CH}_{4} /$ air mixture with a $\mathrm{CH}_{4}: \mathrm{O}_{2}$ ratio of $2: 1$ for cells with LSCF-CGO cathodes in various CGO weight fractions.

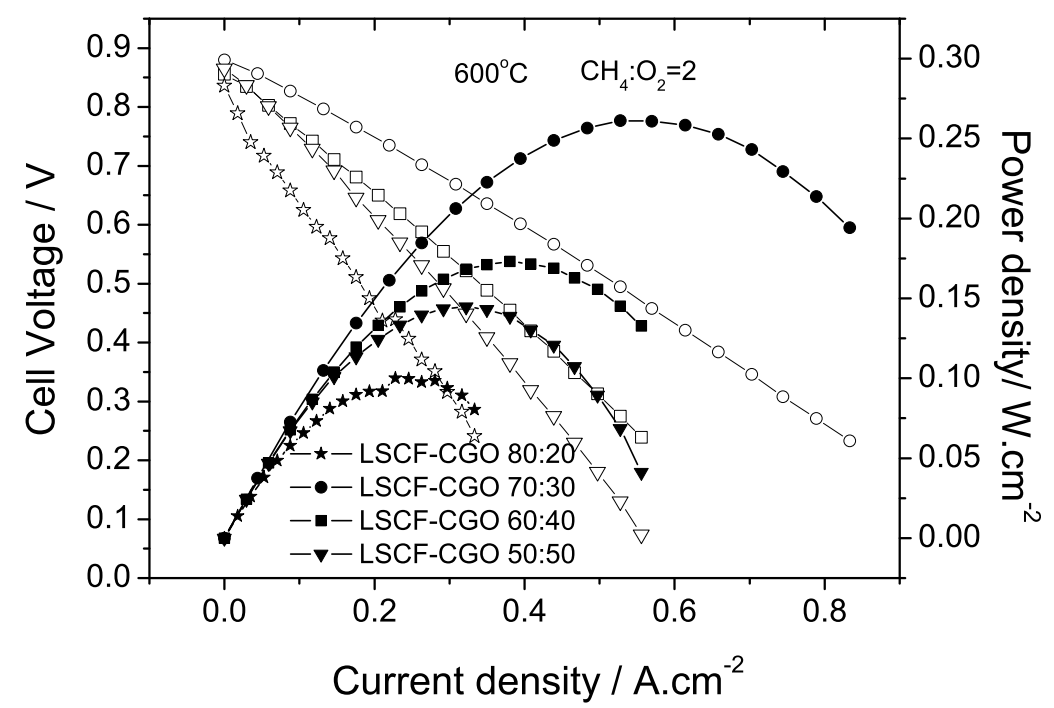

Fig. 8: Exothermic effect $\left(\Delta \mathrm{T}=\mathrm{T}_{\text {electrode }} \mathrm{T}_{\text {furnace }}\right)$ for the cell measurement at different $\mathrm{R}_{\text {mix. }}$
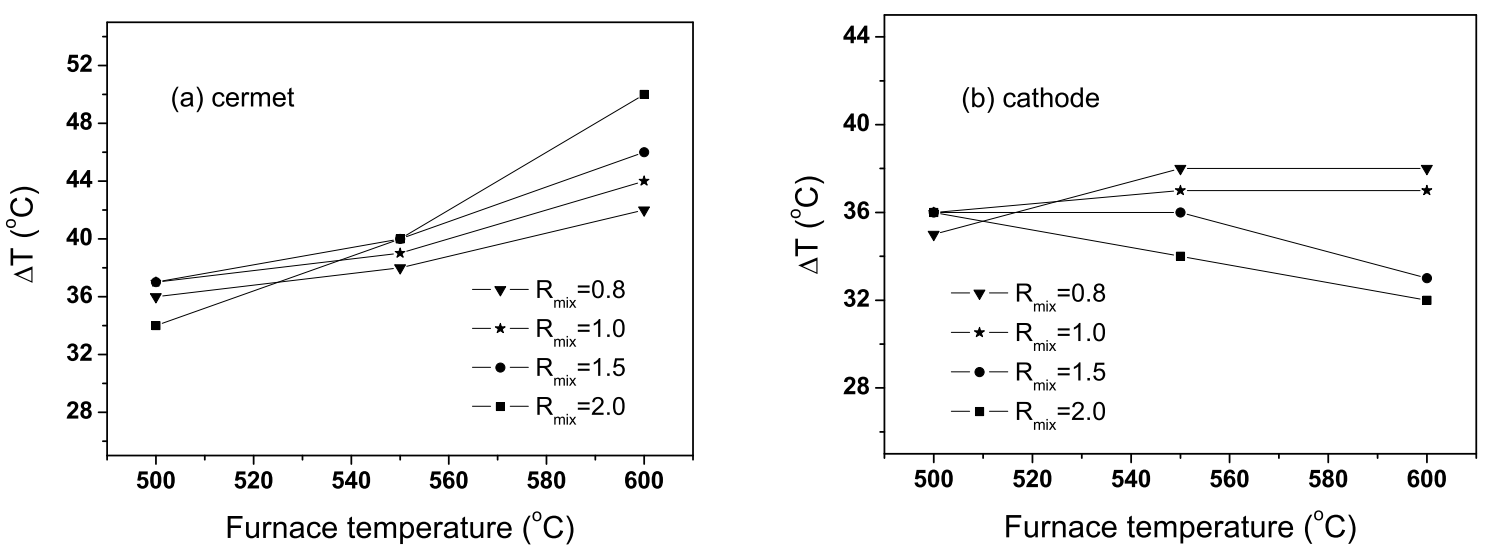
Fig. 9: I-V and I-P curves of the typical fuel cell testing under different temperature (furnace), $\mathrm{R}_{\text {mix }}=2$.

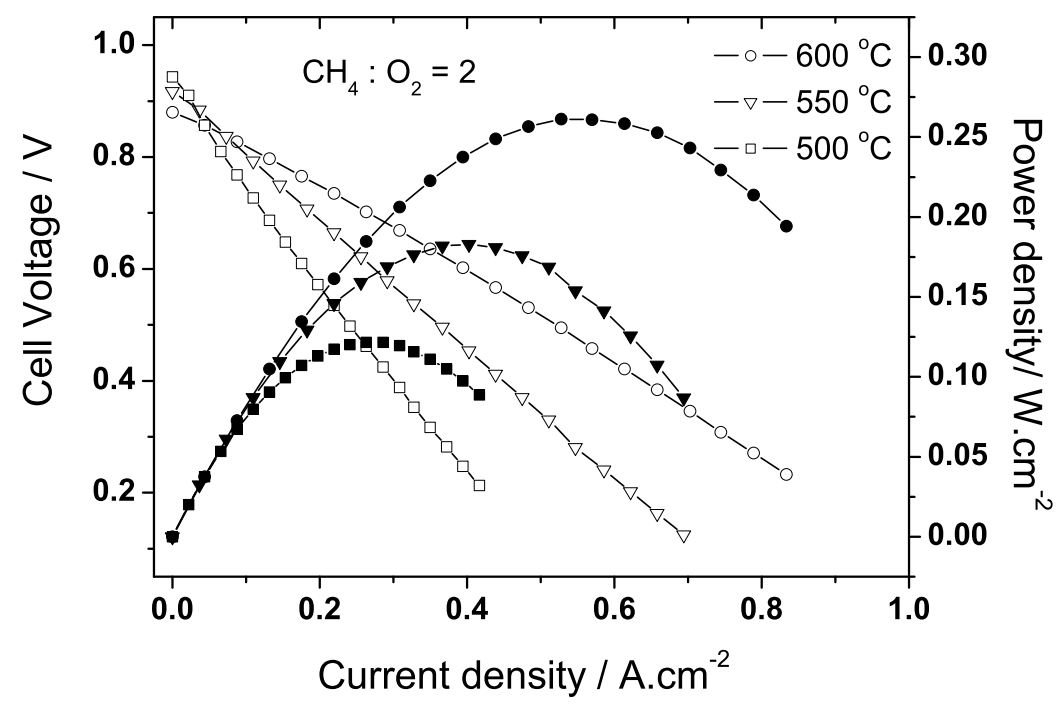

Fig. 10: I-V and I-P curves of the typical fuel cell testing under different $R_{\text {mix }}$ at $600{ }^{\circ} \mathrm{C}$.

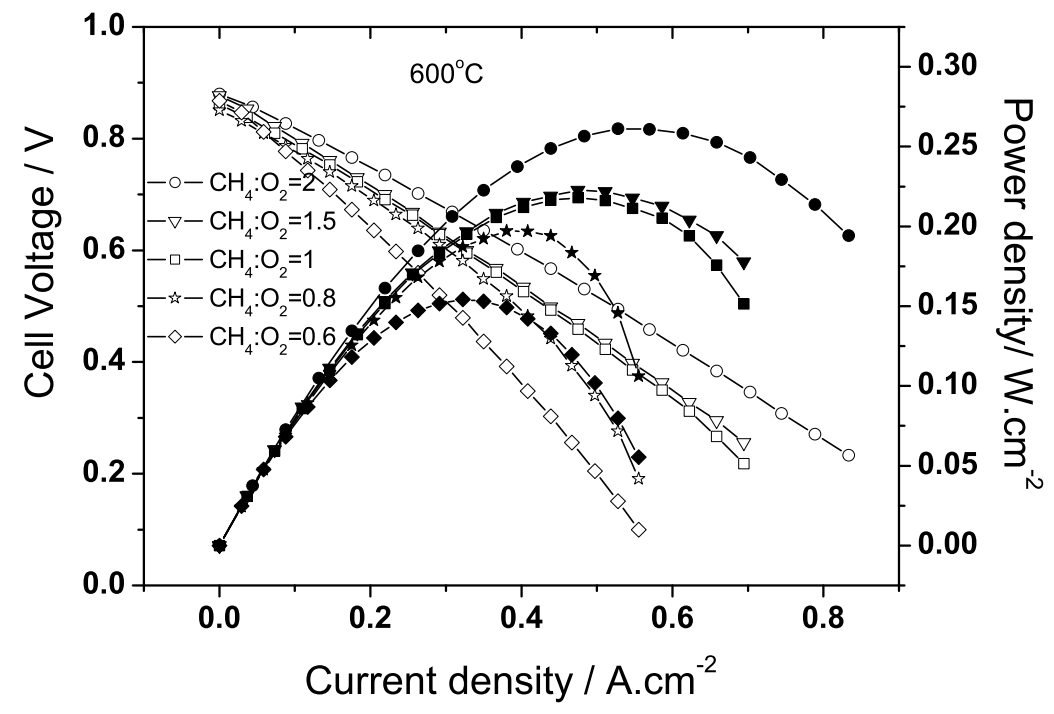


Fig. 11: The OCV of the cell under different $\mathrm{R}_{\text {mix }}$ at different temperature.

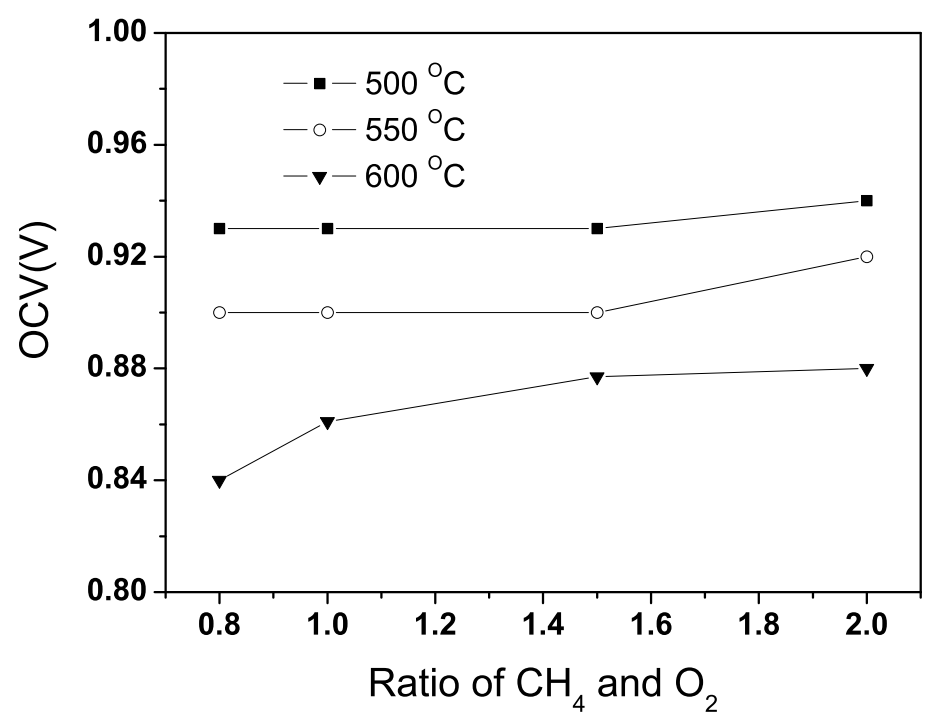

Fig. 12: I-V and I-P curves of the typical fuel cell with different cathode area testing under $\mathrm{R}_{\text {mix }}$ $=2$ at $600{ }^{\circ} \mathrm{C}$.

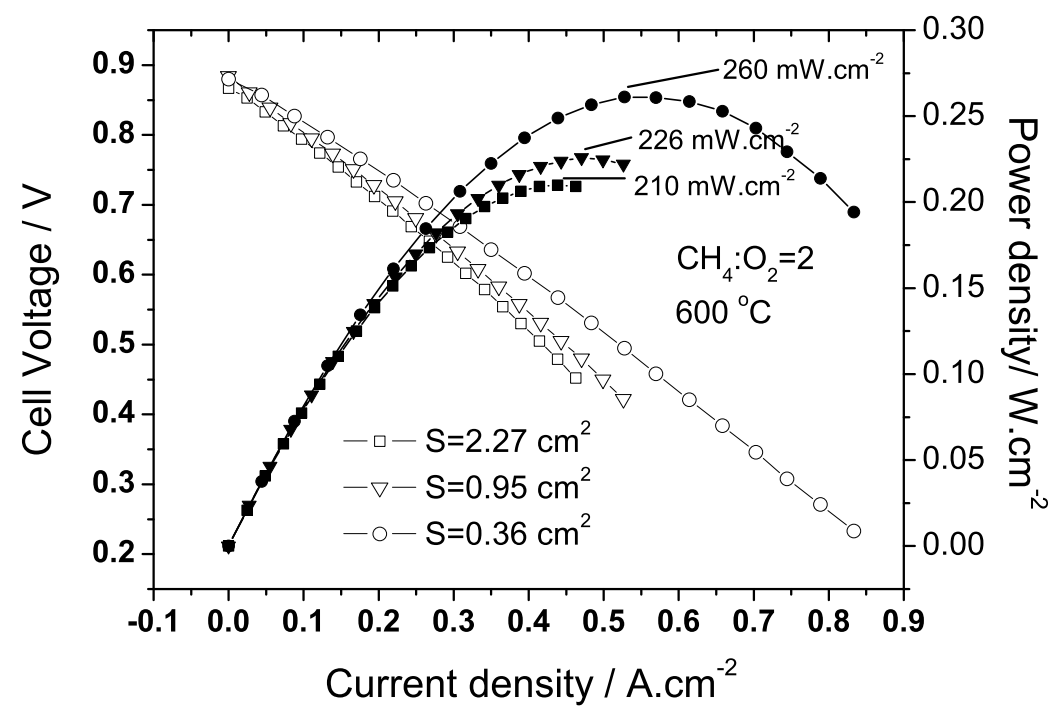

